\title{
JUDICIAL REVIEW OF DISCRETIONARY POWERS IN THE ACTIVITY OF HISTORICAL MONUMENTS PROTECTION BODIES. THE EXPERIENCE UNDER THE CASE LAW OF POLISH ADMINISTRATIVE COURTS ${ }^{1}$
}

\author{
Jerzy Parchomiuk \\ John Paul II Catholic University of Lublin
}

\begin{abstract}
The sovereign nature of the forms of operation of cultural heritage protection authorities, the polarization between the individual interest and the public interest, discretion margin in the activities of the authorities, all these elements create a kind of "explosive mixture", which is the source of the legal disputes between the owners of historical monuments and historical monuments protection bodies. The key element of the guarantee of individual freedom is judicial review of public administration. Therefore, it is a matter of dispute to which extent the public administration is subject to judicial review when performing the tasks entrusted. The aim of this article is to analyze how Polish administrative courts approach the problem. What methodology of the review of discretion margin they use? How they solve the dilemma: who makes the final decision - the body or the court? Do they retain the judicial self-restraint or rather they are willing to interfere in the merits of the decision?
\end{abstract}

Keywords: protection of monuments, judicial review, discretionary powers, decision-making freedom, public and individual interest, property right

\section{INTRODUCTION}

Protection of historical monuments is an area of particular polarization of the public and individual interests. Inevitably, there is a state of tension between the freedom to use the subject of property rights and the public interest expressed in the need to protect one of the key elements of the cultural heritage of the state. Almost every form of monument protection is a limitation of the property right. Protection of historical monuments is an expression of the care for the memory and cultural identity of the nation, and this is an element of the raison dêtre. The State cannot survive without the foundation of history and culture.

The legal forms of the implementation of tasks by the historical monument protection authorities must be sufficiently flexible. The object of protection is of a specific character. To determine what is a monument and, consequently, what is the subject of protection, requires an assessment based on expertise in the field of art, history and science. It is difficult to describe the subject of the protection in an abstract way, using the rigid language of legal norms. This creates the first sphere of discretion margin.

The paper was prepared as part of the research project "Legal acts of the provincial monument conservator", financed from funds of the National Science Centre, Poland (Ref. UMO-2015/19/B/HS5/02525). 
In addition, the administrative body's activities must be adequate to the needs of a particular object of protection, so the body must creatively and dynamically adjust the activities to the needs. This creates the second sphere of discretion margin. The legislature is not able to describe in a rigid way the determinants for taking appropriate protective measures by the authorities.

The sovereign nature of a significant part of the forms of operation of cultural heritage protection authorities, the polarization between the individual interest and the public interest, the necessary discretion margin in the activities of the authorities, all these elements create a kind of "explosive mixture" that creates legal disputes between the owners of historical monuments and historical monuments protection bodies.

In a democratic state governed by the rule of law, an individual must be guaranteed real legal protection against acts of public administration. The key element of the guarantee of individual freedom is judicial review of public administration. Therefore, it is a matter of dispute to which extent the public administration is subject to judicial review. It is about appropriate separation of functions: the public administration is to implement the administrative policy, while the role of administrative courts is to review whether this function is correctly exercised under the legal provisions governing the activity of the administration. Due to the separation of functions, the court cannot substitute the administrative body, and it cannot take a discretionary ruling instead of the ruling the body has issued under its discretionary power. The key question is who has the decisive voice, and who makes the final decision (Letztentscheidung) ${ }^{2}$

The purpose of my article is to analyze how Polish administrative courts approach the problem so defined - what methodology of review of the discretion margin of administration they use as they try to solve the dilemma: who makes the final decision. Whether they retain the judicial selfrestraint or rather in the name of protecting the rights of the owner of the monument, they are willing to interfere in the merits of the decision.

\section{DISCRETION MARGIN IN THE ACTIVITIES OF HISTORICAL MONUMENTS PROTECTION BODIES}

\subsection{Discretion margin in the activities of public administration}

The approach to classifying the types of discretion margin in the activities of public administration bodies differs in different legal systems.

Without going too far into a wider reflection on this subject, it should be remembered that for French administrative law a broad notion of discretionary powers of the administration is characteristic, without strictly distinguishing between its various categories. ${ }^{3}$ The discretionary powers (pouvoir discrétionnaire) are generally described as a situation in which legal rules leave the administration a wide margin of assessment (large marge/pouvoir d'appréciation). In other words: when making a decision, the body has the power to assess the facts as a result of which it can choose

MAURER, H.: Allgemeines Verwaltungsrecht. München: C. H. Beck 2011, p. 142.

Similarly: SCHWARZE, J.: Grundlinien und neure Entwicklungen des Verwaltungsrechtschutzes in Frankreich und Deutschland. In: Neue Zeitschrift für Verwaltungsrecht, 1996, no. 1, p. 25. 
between different decisions, each of which must be judged by the court as lawful. The key elements are the freedom to choose a settlement and freedom of assessment. ${ }^{4}$

Similarly, English administrative law does not pay much attention to classification, focusing rather on delineating the limits of discretion margin. For an English court, more important are the limits in which it can control the use of discretionary powers by the administration, rather than precise conceptual classifications. ${ }^{5}$

In turn, for German-language science, it is characteristic to separate the spheres of the discretionary powers in the activities of public administration through the distinction between discretion (Ermessen) and the vague terms (unbestimmte Begriffe). The notion of discretion should refer only to the element of a legal norm specifying the legal consequences. Discretion occurs when the statutory conditions of the actual state are related to an alternative, equivalent from the point of view of the lawfulness of the settlement. ${ }^{6}$

In the sphere related to the determination of the facts, a form of discretion margin is the concept of free evaluation areas (Beurteilungsspielräume). ${ }^{7}$ The legislature introduces this form of discretion margin in administration activities through the use of vague terms. However, these forms do not constitute a uniform category.

It is distinguished, on the one hand, by the "empirical" notions which can be clarified on the basis of objectively verifiable indicators. Their vagueness is conditioned by the factual circumstances regarding time or place, which means that the meaning of this term in a specific place and at a specific time can be objectively clearly specified (defined). Such a degree of objectivity cannot be achieved in relation to vague terms in the strict sense. In the case of these terms, all that falls under the type is legal, and everything that goes beyond this area is illegal. ${ }^{8}$ It is impossible to state, by cognitive reasoning, what is the correct meaning of the vague term in an individual case. The legally permitted content is on a certain scale of assessments.

The Polish studies of administrative law remain under the influence of the German-language legal scholarly opinion, maintaining the division into two different areas of discretion margin: administrative discretion and other types of freedom of assessment resulting from the use of vague terms. ${ }^{9}$ This is important because Polish courts refer to these concepts, but not always consistently, which will be discussed in further considerations.

4 CHAPUS, R.: Droit administratif général. Tome I. Paris: Montchrestien, 2001, p. 1056; DUBOUIS, L.: La théorie de l'abus de droit et la jurisprudence administrative. Paris: LGDJ, 1962, p. 37; SERRAND, P.: Le contrôle juridictionnel du pouvoir discrétionnaire de l'administration à travers la jurisprudence récente. In : Rev. du droit public, 2012, no. 4, p. 901-902.

5 BRINKTRINE, R.:Verwaltungsermessen in Deutschland und England. Heidelberg: C. F. Müller, 1997, p. 334-337; CRAIG, P.: Administrative Law. 7th ed. London: Thomson, 2012, p. 561-563; WADE, W. - FORSYTH, Ch.: Administrative Law. 9th ed. New York: Oxford University Press, 2004, p. 343-344.

6 MAURER, H.: Allgemeines, op. cit., p. 143-144; ACHTERBERG, N.: Allgemeines Verwaltungsrecht. Heidelberg: C.F. Müller, 1986, p. 345-346.

7 BACHOF, O.: Beurteilungsspielraum, Ermessen und unbestimmter Rechtsbegriff. In: Juristenzeitung, 1955, no. 4, p. 9798.

8 OSSENBÜHL, F.: Rechtliche Gebundenheit und Ermessen der Verwaltung. In: ERICHSEN, H.-U. (ed.): Allgemeines Verwaltungsrecht. Berlin-New York: Walter de Gruyter, 1995, p. 182-183.

9 See: JAŚKOWSKA, M.: Uznanie administracyjne a inne formy władzy dyskrecjonalnej administracji publicznej. In: HAUSER, R. - NIEWIADOMSKI, Z. - WRÓBEL, A. (eds.): System prawa administracyjnego. Tom I. Instytucje prawa administracyjnego. Warszawa: C.H. Beck, 2010, p. 298-303. 


\subsection{The specificity of discretion margin in the monument protection}

Legal regulations defining the tasks of monument protection authorities create a specific accumulation of discretion margin. First of all, there are different species of discretion margin at different levels of regulation: both at the level of the description of the facts (vague terms), and on the other, there is also a typical discretion in the regulations, and thus an element of the description of legal consequences. Secondly, at the level of the description of facts, there is another aspect of the specificity of discretion margin, resulting from a peculiar mix of technical, historical and art-related knowledge, but also assessments of the value. The specificity of discretion margin appears at the very basics the normative definition of the object of protection. Various terminology is used in different legal systems, indicating a broader (cultural heritage) or narrower (historical monument) scope of the concept. The terminology used by the legislature can be dictated by various motives. Of course, the scope of regulation is a general motive - whether it is generally about all the cultural assets (broadly understood), irrespective of the era they come from, or the regulation is to deal with a slightly narrower aspect - "memorabilia of the past" deserving protection as a testimony of the development of cultural heritage in various geographical aspects (global, regional, national).

One example is the Convention Concerning the Protection of the World Cultural and Natural Heritage, which considers a monument a subcategory of the cultural heritage, and therefore covers it with a broader scope of protection. ${ }^{10}$ The Convention describes monuments as part of the cultural heritage and defines them as: architectural works, works of monumental sculpture and painting, elements or structures of an archaeological nature, inscriptions, cave dwellings and combinations of features, which are of outstanding universal value from the point of view of history, art or science. In addition, the Convention protects groups of buildings: groups of separate or connected buildings which, because of their architecture, their homogeneity or their place in the landscape, are of outstanding universal value from the point of view of history, art or science; as well sites: works of man or the combined works of nature and man, and areas including archaeological sites which are of outstanding universal value from the historical, aesthetic, ethnological or anthropological point of view.

However, it is not the only determinant of the methodology used in legal regulations. For example L. V. Prott and P. J. O'Keefe prove the superiority of the term "cultural heritage" over the concept of "cultural property", claiming that the concept of cultural property does not allow the problem of the owner's duties in the protection of the asset to be recognized. ${ }^{11}$ The terminology used in the regulations may, therefore, have a deeper meaning, it constitutes the expression of a specific "legislator's philosophy" in the approach to the problem of protection of historical monuments. Terminology can therefore be one of the guidelines to read the legislature's will regarding protected values, and consequently one of the hints on how to resolve the aforementioned collision of individual and public interests.

Guided by the methodological assumptions adopted at the outset, I will refer to Polish legal regulations. The Polish Act of 23 July 2003 on protection and guardianship of historical monuments uses a narrower concept of a historical monument. ${ }^{12}$ The act defines a historical monument as: immov-

10 Adopted by the General Conference at its seventeenth session Paris, 16 November 1972. The text of the Convention is available at: whc.unesco.org/archive/convention-en.pdf (accessed on $5^{\text {th }}$ November 2018).

11 PROTT, L. V. - O’KEEFE, P. J.: Cultural Heritage or Cultural Property. In: International Journal of Cultural Property, 1992, no. 1, p. 309.

12 Currently: Official Journal 2017, file 2157. Next: APHM. 
able or movable object or part or group thereof, made by man or connected with man's activity and constituting a testimony to a past era or event, the preservation of which is in the interest of society due to its historical, artistic, scientific or academic value (Article 3.1).

The statutory definition of a historical monument contains a number of vague terms, ranging from determining whether an object "a testimony to a past era or event", by assessing its "historical, artistic or academic value", to determining whether the preservation of this object is in the "interest of society". The discretion margin of the body has a different character in each of these elements. The evaluation of historical, artistic or academic value of a historical monument undoubtedly refers to empirical knowledge. However, it is also a reasoning in the sphere of values, that is, assessments, and these can never be fully objectified.

A number of key questions from the point of view of the judicial review of the public administration arise: who is to assess - do the officials employed in the historical monuments protection bodies have adequate knowledge in this regard? How to make the assessments more objective? Which criteria should be adopted, especially by the administrative court? I will get back to these questions later, because they are directly related to the issue of the methodology of judicial review of discretion margin of historical monuments protection authorities, in the jurisprudence of Polish administrative courts, which is essential to my article.

The most susceptible element to the possibility of an objective approach seems to be the concept of "testimony to a past era or event". On closer examination, such a statement becomes doubtful. There are questions: what is this past era, what are its chronological limits? What criteria should be adopted when setting these limits? ${ }^{13}$ The colloquial way of perceiving a historical monument seems to point to a distant time frame, but after all, a past era can be defined by the period of the previous socio-political and economic system. If the aim of protection of historical monuments is to protect the evidence of the state's cultural heritage in various stages, it is difficult to overlook the shorter time perspective, in this way we can deprive future generations of material testimonies of the past. Although this is a near past for us, but for future generations the prospect of looking at the historical character of this type of objects will be completely different. Nevertheless, the adoption of a shorter temporal perspective pushes us to the boggy ground of assessments that are no longer legal but political.

This shows the analysis of the last of the conditions from the definition of the monument: to recognize an object as a historical monument, it is necessary to investigate whether its preservation "is in the interest of the society".

This is perhaps the most problematic of the conditions that make up the definition of a historical monument. First of all, the notion of social interest is the so-called general reference clause. The essence of a general reference clause is the authorization for the body to determine the basis for qualifying the activity of the addressee of the norm based on criteria that are expressed in the legal text, but their content has not been incorporated into the legal system, is outside this system. ${ }^{14}$ To determine what elements, what factors in the conditions of a case express the public interest, requires making evaluative, axiological assessments. However, the public interest must be based on

13 PŁAŻYŃSKA, K.: Świadectwo minionej epoki czy dobro kultury współczesnej? Problemy ochrony prawnej architektury nowoczesnej. In: ZEIDLER, K. (ed.): Prawo ochrony zabytków. Warszawa-Gdańsk: Wolters Kluwer, 2014, p. 108.

14 LESZCZYŃSKI, L.: Stosowanie generalnych klauzul odsyłających. Kraków: Zakamycze, 2001, p. 21; JAKIMOWICZ, W.: Wykładnia w prawie administracyjnym. Kraków: Zakamycze, 2006, p. 124-125; WRÓBLEWSKI, J.: Wartości a decyzja sądowa. Wrocław: Ossolineum, 1973, p. 211. 
law, so the public interest refers to assessments in the sphere of the axiology of the legal system. The desired state can be considered to be in the public interest only if it passes through the "filter" of the axiology of the legal system. ${ }^{15}$

If we take into account previous considerations regarding the concept of "testimony of a past era", in this way legal assessments may become entangled with political assessments. If in the perspective of the values on which the new system is based, the previous system is assessed extremely negatively, it is deemed necessary to remove the material remnants of this system from the public space. Thus a conflict of values arises at the level of legal policy (in terms of both lawmaking and applying the law): should we protect the evidence of the previous system existing in the public space, regardless of the negative assessments of this system, because they are evidence of a bygone era and, therefore, of cultural changes in the country? Or maybe we need to remove these objects as symbols of values that are contrary to those on which the current social and political system is based? Such discussions are characteristic for the countries of Central and Eastern Europe, due to the political changes that occurred at the turn of the 80 s and 90 s of the last century.

The assessment of whether the preservation of the object is in the social interest must take into account a huge range of factors. On the one hand, the care for the memory of the cultural identity of the nation requires preserving as much evidence of the past as possible. On the other hand, protection means restrictions of the right to property and, hence, social costs. Contrary to appearances, in many situations the financial criterion becomes important: the problem of financing the protection. In the face of limited public resources, we often face an answer to the question of whether we can afford a very wide range of protection of historical relics.

The numerous discretion margin clauses presented in the definition of historical monument induce many authors to criticize the definition adopted by the Polish legislature. The authors formulate postulates of greater precision in the definition of historical monument and the departure from the use of vague terms. ${ }^{16}$ In my opinion, this is an expression of misunderstanding of the application of law in such a specific field as the protection of historical monuments. It is just because of the need to seek a compromise between the interests of the owner and the public interest. A too rigid legal regulation makes it impossible to find the right solution.

The granting of discretion margin to the public administration bodies is also an expression of a certain degree of trust of the legislature. Sometimes the legislator does not want to regulate a specific issue in a strict way, because it wants to leave some freedom to the body. ${ }^{17}$

Of course, there is another side of this coin - to be trusted, a law enforcement body must be a specialist. In this context, the following question remains: do officials employed in the historical monument protection administration have adequate expertise in history, art and technology? Are they capable of performing their tasks in terms of these competences, or are they also using third-party expertise due to deficiencies in this area? ${ }^{18}$ The specificity of vague terms contained in

15 PARCHOMIUK, J. Nadużycie prawa w prawie administracyjnym. Warszawa: C.H. Beck, 2018, p. 620-621.

16 KOWALSKI, W. - ZALASIŃSKA, K.: Strategia regulacji prawa ochrony dziedzictwa kulturowego. In: ZEIDLER, K. (ed.): Prawo ochrony zabytków. Warszawa-Gdańsk: Wolters Kluwer, 2014, p. 75; PŁAŻYŃSKA, K.: Świadectwo, op. cit., p. 105; TRZCIŃSKI, M.: Definicja zabytku archeologicznego - problemy i kontrowersje wokół stosowania prawa. In: Ibid., p. 115-122.

17 LESZCZYŃSKI, L.: Stosowanie, op. cit., p. 232-233.

18 KOBYLIŃSKI, Z. - WYSOCKI, J.: Ujęcie problematyki ochrony zabytków archeologicznych w ustawie o ochronie zabytków i opiece nad zabytkami - stan obecny i postulaty zmian. In: ZEIDLER, K. (ed.): Prawo ochrony zabytków. WarszawaGdańsk: Wolters Kluwer, 2014, p. 134. 
the legal definition of historical monument results is that their interpretation and application in a specific case requires scientific knowledge. Therefore, the question arises: will a decision-making officer, who does not have adequate knowledge but who relies of third-party expertise, be able to make good use of discretion margin? This is a problem of administrative policy in the field of creating human resources bodies responsible for the protection of monuments. The problem has a legal aspect in that it is up to the legislator to formulate any requirements as to the employed, at least at the decision-making positions. As I will show in the next part of the discussion, the Polish administrative courts show more confidence in the specialist knowledge of officials employed in the monument protection bodies.

The statutory elements of the definition of the subject of protection determine the first "circle" of discretion margin of monument conservation bodies. The legislator creates the next circle of discretion margin by defining the premises for applying specific forms of interference. To describe these premises, the legislator often uses indefinite terms, and in some cases introduces an even wider discretion margin in the form of administrative discretion. Duplication of both areas of discretion margin significantly increases the level of vagueness in the limits of interference.

Examples of this are institutions of temporary seizure of the movable or immovable monuments. These are more moderate forms of interference than the more radical expropriation of the monument. According to article 50.1 of the APHM, in the event of a threat to a movable monument entered into the register in the form of its potential destruction, damage, theft, loss or illegal export abroad, the voivodeship inspector of monuments may issue a decision on securing this monument in the form of a temporary seizure until the threat has been removed. Whereas in the light of Article 50.3 of the Act, in the event of a threat to an immovable monument entered into the register in the form of its potential destruction or damage, the head of the district, upon a request of the voivodeship inspector of monuments, may issue a decision on securing this monument in the form of a temporary seizure until the threat has been removed.

The notion of threat to a historical monument belongs undoubtedly to the above-mentioned empirical vague terms. In their case, there is the possibility of objective concretization and refinement. The authority using this form of restriction must provide specific arguments referring to the factual situation, when indicating the threat. This argumentation is in principle subject to full control of the administrative court, however, taking into account the specificity of the judicial model of control, which limits the role of the court to the verification of evidence gathered by the authority.

Such forms of protection of monuments are based on classic administrative discretion: awarding the status of a monument of history (by an ordinance of the President of the Republic of Poland; Article 15.1) or establishing of a cultural park (by a resolution of the commune council; Article 16.1 of the APHM). The discretion of the bodies in this case is limited by the conditions set out in the act, therefore the discretion is of a targeted nature. Nevertheless, the reasons that limit the freedom of the authorities are in the form of indefinite terms, which is the source of a different kind of discretion margin and weakens the legal limits on the use of discretionary powers. In the first example: the status of a monument of history can be given to a monument or park of special value for culture

In turn, a cultural park is established in order to protect a cultural landscape and preserve areas of outstanding landscape with immovable monuments characteristic of local construction and settlement tradition. The body introducing this form of monument protection must assess, among other things, whether we are dealing with elements characteristic of the local building and settle- 
ment tradition. This is empirical knowledge that can be controlled based on some criteria. However, the question arises whether the administrative court, unable to appoint experts independent of the authority, is able to verify the correctness of such classification.

Generally speaking, in the case of discretionary forms of action, the decision-making power of the body is partially limited by legally determined premises, however, sometimes these premises are formulated using indefinite terms, which opens up another sphere of discretion margin and weakens the restriction of administrative discretion.

Sometimes the legislature tries to clarify the conditions by referring to objectively measurable assessment criteria. An example is the entry of a movable monument into the List of Heritage Treasures (the entry is made by the minister competent for culture and protection of national heritage, Article 14a of the APHM). In this case, the legislator uses premises of a different nature of discretion margin. On the one hand, we have a vague term: it is to be a "monument of special value to cultural heritage". This is a typical vague term of an evaluative character, its interpretation is not subject to fully objective measures, the evaluations will be on a certain scale. On the other hand, the monument must be included in the category specified in the Act, described with the use of measurable criteria: age (over 50,75, 100 or 200 years, depending on the monument and category) and value (EUR 15,000, 30,000, 50,000, depending on the monument and category. ${ }^{19}$

However, there is a problem, to what extent these indicators reflect something significant from the point of view of values subject to protection in the historical monument protection law. This is clearly visible on the example of the category of photographs, films and negatives. In this case, the analyzed form of protection covers objects of this type that are more than 50 years old, their value is higher than 15,000 euro and they are not owned by their creators (Article 14a.1.8 of the APHM). Of course, the age of a photograph can be relatively easily determined, but how to assess the value of a photograph? The material value, if determined by the market price, may not have any impact on the value of the object as a testimony of the past or culture of a nation.

The legal form of the authority for the protection of monuments may also be a source of discretion margin. An example is the choice of a less formalized form (entering the object into the voivodeship lists of monuments) instead of an entry in the register of the monuments. This choice may be motivated by the intention of the authority avoiding a more formal procedure, which can in extreme cases be assessed in the context of abuse of the procedure. I will return to the problem more broadly in point 3.5.

\section{DETERMINANTS OF THE JUDICIAL REVIEW OF DISCRETION MARGIN}

There are three factors determining the court's approach to controlling the use of discretionary powers by the administration. They relate to the systemic functions of public authorities, the criteria for judicial review and the institutional capacity of courts to exercise administrative control.

19 A similar method was used in art. 51.1 of the Act. This provision specifies cases in which a single permit for permanent export abroad is required. Also in this case, setting out the conditions for the requirement to obtain a permit, the legislator referred to objectively measurable criteria of age and value. 


\subsection{Constitutional conditions}

Constitutionally shaped roles of public authorities, resulting from the division of power, result in that the primary responsibility for shaping and implementation of social and economic policy rests with the legislature and executive. The task of the judges is to control the administration, not to discuss and speculate about social, economic or political preferences. ${ }^{20}$ The role of courts is to stop any excess from the limits of the powers. On the other hand, the court must respect the will of the legislature, which can broadly define the scope of the discretion margin of the public administration, bearing in mind the reasons of expediency, better implementation of public tasks. Executive functions in the state cannot be seen in the categories of "subsumption automate"(Subsumtionautomat), a blind executor of orders of the legislature. It is necessary to leave to public administration bodies a certain area of freedom to act on their own responsibility while performing the tasks entrusted. ${ }^{21}$ Due to the principle of separation of functions, the court cannot replace the body, it cannot, in place of the decision left to the discretion of the body, make its own discretionary decision. ${ }^{22}$ On the other hand, it is difficult to assume that for the legislature the power should be open to serious abuse. The legislature assumes that the body will act properly and responsibly, taking into account the best solution from the point of view of public interest and in accordance with the policy specified in the Act. For this reason, the courts must ensure that the legal limits of each, even the widest discretion, are respected. ${ }^{23}$ As Dworkin put it, "Discretion, like the hole in a doughnut, does not exist except as an area left open by a surrounding belt of restriction", ${ }^{24}$ it is not a lawless void.

The review powers of the court gain additional legitimacy in cases concerning violation of human rights. Even a wide general power must make way for fundamental rights. Courts have the legitimacy to defend against interference in these rights, it is the basis of constitutional democracy. ${ }^{25}$ This means less restraint of the courts, more intensive application of the criteria for the review of discretionary acts where interference with fundamental rights is involved. ${ }^{26}$

\subsection{Legality as a criterion for judicial review}

Due to the constitutional separation of the functions of public administration and the courts that control it, judicial review covers only the legality of an administrative act, its compliance with legal rules that determine the work of the administration. If such a legal rule allows the administrative body to act freely, the body decides based on opportunity (opportunité). The administrative court

20 WOOLF, H. Lord - JOWELL, J. - LE SUEUR, A.: De Smith's Judicial Review. 6th ed. London: Sweet \& Maxwell, 2007, p. 16-17 and the case-law cited there; CRAIG, P.: Administrative Law, op. cit., p. 6; WADE, W. - FORSYTH, Ch.: Administrative Law, op. cit., p. 345.

21 ACHTERBERG, N.: Allgemeines Verwaltungsrecht, op. cit., p. 336 and 340.

22 Bundesverwaltungsgericht: 9 Mai 1956 (III C 123.54, BVerwGE 3, 279); WOLFF, H. J. - BACHOF, O. - STOBER, R.: Verwaltungsrecht I. München: C.H. Beck, 1994, p. 378; HÄFELIN, U. - MÜLLER, G.: Grundriss des Allgemeinen Verwaltungsrechts. Zürich: Schulthess, 1998, p. 93-94; RODE, L.-H.: $\$ 40$ VwVfG und die deutsche Ermessenslehre. Frankfurt am Main: Peter Lang, 2003, p. 95-98.

23 WADE, W. - FORSYTH, Ch.: Administrative Law, op. cit., p. 350: “(...) the courts take their warrant to impose legal bounds on even the most extensive discretion)".

24 DWORKIN, R.: Taking Rights Seriously. Massachusets: Harvard University Press, 1978, p. 31

25 WOOLF, H. Lord - JOWELL, J. - LE SUEUR, A.: De Smith's Judicial Review, op. cit., p. 18; WADE, W. - FORSYTH, Ch.: Administrative Law, op. cit., p. 393.

26 CRAIG, P.: Administrative Law, op. cit., p. 566-567. 
does not review opportunity. ${ }^{27}$ As Georges Vedel notes, if the administration operates within circumscribed powers, its activities can be assessed in terms of their legality. The public administration can only decide to the extent allowed by law. Its act may, therefore, be compliant or non-compliant with law. On the other hand, if the administration has discretionary powers, its act can only be judged in terms of reasonableness: the act may be opportune or not opportune, right or wrong, but it cannot be illegal until the administration has the freedom to act. ${ }^{28}$

Since the legislation grants the body freedom to assess, the court cannot examine it, because there are no criteria for assessing what are the rules determining the way the body acts. Consistently following this argument, it would entail allowing any arbitrariness of the administration, and thus the possibility of abuse of the body's discretion in the area of assessing the factual basis of the decision.

Therefore, constructs have been developed to prevent leaving the discretionary sphere of administration activities out of the scope of judicial review. These include the concept of manifest error in assessment (erreur manifeste d'appréciation), also known in European administrative law. ${ }^{29}$

\subsection{Institutional capacity of courts to control the discretionary powers of the administration}

The third factor shaping the scope of judicial review of the discretionary powers is the so-called institutional capacity of courts. This factor consists of various components. The first of these is the model of judicial review adopted in a legal system: whether the responsibilities of the court are solely of a controlling or a substantive nature? What is the admissible scope of evidence proceedings before the courts? If in the model of the judiciary it was assumed that the court has only a control function (it reviews the legality of the contested act), the admissibility of the court's own factual findings will be significantly reduced. The court's role will be the control of whether the body correctly established these facts (in accordance with the rules of evidence) rather than independent determination of facts. The problem is well illustrated by the example of the Polish model of judicial review, in which there is no possibility to appoint expert's opinion evidence, which undoubtedly hinders judicial review. I will return to this issue in further considerations.

The second component within the analyzed factor is the nature of discretion margin. In those legal systems, in which different sphere of discretion margin is distinguished, the case law shows greater restraint by courts in the scope of control of administrative discretion. Courts are limited to review the compliance with statutory limits of discretion and the compliance with procedural requirements.

Furthermore, here comes the third element shaping the institutional capacity of the courts to review the case: the matter of the case in which the act was issued. It is believed that there are some

SERRAND, P.: Le contrôle juridictionnel, op. cit., p. 906.

28 VEDEL, G. - Delvolvé, P.: Droit adminitstratif, T. 1. Paris: Presses Universitaires de France, 1992, p. 529.

29 European Court of Justice in Judgement of 25 January 1979 (98/78, A. Racke v Hauptzollamt Mainz, ECLI:EU:C:1979:14, $\$ 5)$ : “[... since the evaluation of a complex economic situation is involved, the Commission enjoy, in this respect, a wide measure of discretion. In reviewing the legality of the exercise of such discretion, the Court must examine whether it contains a manifest error or constitutes a misuse of power or whether the authority did not clearly exceed the bounds of its discretion". See also: VAN RAEPENBUSCH, S.: Droit institutionnel de l'Union et des Communautés européennes. Bruxelles: Larcier, 2001, p. 509-510; TOTH, A.: The Oxford Encyclopedia of European Community Law. Oxford: Oxford University Press, 2005, p. 368. 
spheres of administration activity in which decisions are not "predestined" for judicial review. These include the issues of choosing the preferred objectives of socio-economic policy; decisions in fields which require highly specialized, expert knowledge that courts do not have; decisions regarding the distribution of limited resources, where a possible change in the authority's decision by the court will trigger a chain of events requiring the change of other decisions; assessment decisions of independent experts; complex prognostic and risk-based decisions. ${ }^{30}$

\subsection{Judicial self-restraint}

The key issue for the understanding of the models of judicial review of the discretionary powers is the fundamental principle that the role of the court is not to substitute the administration with regard to the merits of decisions. This concept, accepted in various legal systems, is particularly emphasized in English administrative law. An example of this may be the argumentation of Judge Laws in the case Somerset County Council, ex parte Fewings. ${ }^{31}$ Trying to explain the essence of judicial review, Judge Laws stated:

"It is that, in most cases, the judicial review court is not concerned with the merits of the decision under review. The court does not ask itself the question "Is this decision right or wrong?" Far less does the judge ask himself whether he would himself arrived at the decision in question. [...] The only question for the judge is whether the decision taken by the body under review was one which it was legally permitted to take in the way it did."

Judicial self-restraint does not mean weakening the efficiency of judicial protection of individual rights. This is the expression of a change in the methodology of judicial review of discretionary powers, which is characterized by two features. First, the courts prefer the so-called rights-based approach, whose main assumption is that the courts interpret the scope of discretionary powers in accordance with the guarantees of fundamental rights, if it is possible. The second characteristic feature is the change of court approach to the discretionary power in public law - the transition from the "culture of authority" to the "culture of justification", which obliges the author of the decision to carefully consider the relationship between the means and the purposes for which the decision was issued. Courts require a richer explanation of the decision, although its merits will remain at the discretion of the author of the decision (authority). It is the duty of the authority to indicate the factors that were taken into account and to explain why one of them gave priority to others. The courts require a particularly scrupulous justification for such discretionary decisions that lead to a conflict with fundamental rights. ${ }^{32}$

Both of these features are visible in the methodology of review of the discretion margin of historical monuments protection authorities, applied by Polish administrative courts. I will refer to this issue in more detail further on.

30 WOOLF, H. Lord - JOWELL, J. - LE SUEUR, A.: De Smith's Judicial Review, op. cit., p. 19-20, 547-549; MAURER, H.: Allgemeines Verwaltungsrecht, op. cit., p. 159-160; OSSENBÜHL, F.: Rechtliche Gebundenheit, op. cit., p. 196-201; WOLFF, H. J. - BACHOF, O. - STOBER, R.: Verwaltungsrecht I, op. cit., p. 368-370; SCHENKE, W.-R.: Verwaltungsprozessrecht. Heidelberg - München: C.F. Müller, 2012, p. 261-262; ODE, L.-H.: $\$ 40$ VwVfG, op. cit., p. 53-57.

31 High Court (Queens Bench Division): 10 February 1994, [1995] 1 All ER 513.

32 WOOLF, H. Lord - JOWELL, J. - LE SUEUR, A.: De Smith's Judicial Review, op. cit., p. 17, 544, 597. 


\section{THE SPECIFICITY OF DISCRETION MARGIN IN THE ACTIVITIES OF MONUMENT PROTECTION BODIES AND THEIR JUDICIAL REVIEW}

Judicial review of administrative acts of historical monument protection bodies illustrates all the above-mentioned problems of judicial review of the discretionary powers.

Particularly noticeable is the complex problem of delineating the limits of admissible interference by the court, resulting from the fact that the role of the court is to review the implementation of the administrative policy, not the independent implementation of this policy. Since the historical monument protection bodies implement the policy of protection of cultural heritage adopted by the state, administrative courts should intervene in this area with a great caution.

On the other hand, courts must enforce compliance by administrations with the rule of law and provide the individual with effective legal protection. As I mentioned in the introduction, a characteristic feature of most forms of operation of historical monument protection bodies is a deep interference in the sphere of individual rights. This is due to the strong polarization between the interest of the owner of the monument and the public interest, expressed in the need to protect the evidence of cultural heritage of the State. Courts must therefore walk along a narrow and bumpy road leading between respecting the functions of administration implementing the policy of protection of historical monuments and the need to ensure effective and not only illusory judicial protection for the owner of a historical monument.

Further problems arise from the fact that the criterion of judicial review is legality. The effectiveness of judicial review depends on the possibility of building a reference standard, which will serve as a model for the review of the contested act. This is where the fundamental difficulty arises, resulting from the specificity of the activities of the monument protection bodies. The nature of discretion margin makes it difficult to formulate objectively verifiable criteria for assessing administration activities that are based on law.

What is more, the activities of historical monument protection bodies are largely based on non-legal norms, in particular the so-called monument preservation rules. These rules do not have a normative form such as the law. They are therefore the source of a kind of discretion margin for historical monument protection authorities. These unspecified criteria often provide historical monument preservation bodies with guidelines on the imposition of specific duties on the monument's owner. Due to the fact that these principles, on the one hand, are of a non-legal nature, on the other, significantly determine the activity of historical monuments protection bodies, deciding about significant interferences in the sphere of property law, there are postulates in the literature to include these principles in the form of legal acts falling within the constitutional catalog of sources of law. ${ }^{33}$

These postulates, though probably right, seem difficult to implement. Considering the divergence of scientific views, the fundamental question is whether the body is capable of establishing permanent (at least relatively) principles that can be expressed in the language of abstract legal

33 ZEIDLER, K.: O znaczeniu teorii konserwatorskiej w procesie stosowania prawa. In: SZMYGIN, B. (ed.): Współczesne problemy teorii konserwatorskiej w Polsce. Warszawa-Lublin: Międzynarodowa Rada Ochrony Zabytków ICOMOS, 2008, p. 173-180; TAJCHMAN, J.: Konwencja o ochronie dziedzictwa architektonicznego Europy a przyczyny jego degradacji w Polsce oraz drogi do jej powstrzymania. In: ZEIDLER, K. (ed.): Prawo ochrony zabytków. WarszawaGdańsk: Wolters Kluwer, 2014, p. 91. 
norms. Moreover, these principles are, by their essence, very general, and so there would be a need to interpret them in the light of specific facts.

In relation to the review of acts in the field of historical monuments protection, also the problems of the institutional capacity of courts to control the discretionary powers of the administration emerge.

In cases where the object of judicial review is a decision based on specialist knowledge in the field of history, art and technology, the institutional capacity of the court significantly determines the rules specifying the rules for evidence-taking proceedings before a court. For obvious reasons, the court does not have such a level of expertise to independently review the assessments of the body, based on such knowledge. The effectiveness of judicial review therefore depends on the admissibility of the court to summon an external expert to obtain answers on issues related to the correctness of the assessments of a monument protection authority.

In the Polish model of judicial administrative review, evidence proceedings before a court are limited solely to additional documentary proof, if this is necessary to resolve substantial doubts and will not extend excessively the proceedings on the case (Article 106.3 The Act of $30^{\text {th }}$ August 2002 Law On Proceedings before Administrative Courts ${ }^{34}$ ). The lack of the possibility to use the assistance of an independent external expert undoubtedly weakens the efficiency of judicial control of the activities of historical monument protection bodies based on arguments referring to specialist knowledge.

Analyzing the problem of institutional capacity of courts, it should also be noted that not all forms of protection of historical monuments are subject to judicial review.

An example may be awarding the status of a monument of history, where interference takes the form of an ordinance of the President of the Republic of Poland, and thus an act that is not reviewable by administrative courts in the Polish legal system. This does not mean, however, that forms of protection taking the form of general acts are excluded from the administrative courts' review. A similar form of protection - establishment of a cultural park - is introduced in the form of a resolution of the commune council, which is subject to full judicial review (Article 3.2.5 LPAC).

\section{METHODOLOGY OF THE JUDICIAL REVIEW OF DISCRETIONARY MARGIN OF HISTORICAL MONUMENTS PROTECTION BODIES IN THE CASE LAW OF POLISH ADMINISTRATIVE COURTS}

\subsection{A way to understand discretion margin}

Proper court recognition of the type of discretion margin that the authorities of monument protection have at their disposal is crucial for the effectiveness of judicial review. The discretion margin is diverse, and the scope of the review and the "depth" of the court's interference in the content of the decision should be adapted to the kind of freedom (in particular, a significant distinction between administrative discretion and indefinite terms).

Analysis of the case law shows that the courts do not always see these differences and do not always correctly recognize the type of discretion margin that the legislators have granted to the

34 Dziennik Ustaw (Official Journal) 2018, file: 1302; in next: LPAC. 
authorities. One can also notice the lack of uniformity of views expressed in the case-law. In some situations, the responsibility for the lack of consistency of the courts in the analyzed area is on the legislature, which does not specify the conditions of the protection of historical monuments.

According to the traditional view, administrative discretion refers to the choice of the consequences of the established facts, the assignment of this form of discretion is confirmed by the modal phrases included in the regulation, such as "the body may".

However, legal practice creates a more complicated situation in which the sources of discretion margin can result simply from the lack of clearly defined criteria for issuing an act. An example is the basic form of historical monument protection, which is an entering into the register of monuments. In the content of the legal basis of this act (Article 9.1 of the Act on protection of historical monuments), it is in vain to look for the characteristic feature of administrative discretion, which is the modal expression "the body may". According to this provision, immovable monuments shall be entered into the register pursuant to a decision issued by the voivodeship inspector of monuments ex officio or upon a request of the owner of an immovable monument or the perpetual lessee of the land on which an immovable monument is located. It should be noted, however, that the legislature did not specify any conditions, so it is not known what criteria the authority should follow when entering the monuments in the register.

It is even more important because not every monument is entered into the register. The legislature also introduced a less restrictive form of protection, which is the entering of the object into the voivodeship lists of monuments (commune inventory of monuments; Article 22 of the APHM). The question arises, where is the "demarcation line" between these two forms of monument protection? This problem will be discussed further on.

Polish administrative courts are not unanimous about what form of discretion margin we deal with in the analyzed case. On the one hand, it is to note the judgments where it is emphasized that the decision to enter the historical monument into the register is not discretionary, it is a different kind of discretion margin, based on the vague terms. If the authority determines that the object has the features specified in the statutory definition of a historical monument, it is obliged to enter this object into the register of historical monuments. The specification of the reasons for making an entry into the register using vague terms ("a testimony to a past era or event, the preservation of which is in the interest of society due to its historical, artistic, scientific or academic value"), does not constitute grounds for accepting the thesis about the operation of an administrative body based on administrative discretion. These terms are of an evaluative nature and therefore are subject to clarification in the process of applying the law. ${ }^{35}$

The quoted argumentation of the courts indicates a reference to the classic views of the scholars of law, distinguishing the sphere of discretion margin, characterized by a different scope of freedom (the discretion margin resulting from the use of vague terms is different than that resulting from the classical administrative discretion).

On the other hand, opposing views can be noted, indicating that the decision to enter a historical monument in the register is discretionary.

In this case law, the courts observe that the provisions governing the entry of an object into the register of historical monuments do not introduce detailed criteria which the authority should fol-

35 Supreme Administrative Court: 31 October 2012 (II OSK 1115/11); 11 April 2013 (II OSK 2382/11); 24 August 2017 (II OSK 1052/15). All cited judgements are available on the website: orzeczenia.nsa.gov.pl (accessed on 5th November 2018). 
low in assessing the desirability of covering a monument with protection. The decision of the body is therefore discretionary and is based on the evaluation of a subject through the prism of the statutory definition of historical monument, the documentation collected and knowledge and experience of the voivodeship inspector for historical monuments and employees of the voivodeship office for historical monuments. ${ }^{36}$

The above arguments can be considered justified in the absence of precise determination of the criteria of the entry of a historical monument into the register and the absence of the abovementioned line defined by the legislature, drawing a line between the cases when the monument is subject to entry in the register and when it is subject to other forms of protection.

More controversial are judgments in which courts, contrary to the views of the scholars of law, clearly combine different spheres of discretionary power. An example is the judgment of the Voivodeship Administrative Court in Warsaw of 17 January 2013 (I SA/Wa 1041/12), providing for that the decision on the approval for a building insulation is discretionary in the sense that the assessment of the conditions of the decision is made on the basis of vague terms the interpretation of which must be made during the application of law in an individual case. Once these conditions are established by the authority, its resolution is binding by their nature.

The Court's argumentation method is definitely irrelevant. First of all, the provision cited by the court clearly does not give grounds for the authority to act in the context of administrative discretion. Pursuant to Article 36. 1. 1 of the APHM, a permit from the voivodeship inspector of monuments shall require carrying out preservation, restoration and construction works in relation to a historical monument entered into the register. Secondly, the court, contrary to the views of scholars, confuses two different areas of discretion margin: the use of vague terms and administrative discretion. Thirdly, the argument that the decision is no longer issued under the conditions of administrative discretion but is a binding decision, because the authority determined the meaning of the vague term under the conditions of a specific factual state, it becomes completely incomprehensible. Such a method of argumentation cannot be accepted by any means. ${ }^{37}$

Another example may be the judgment of the Voivodeship Administrative Court in Warsaw of 20 February 2018 (VII SA/Wa 1059/17), wherein the Court stated that the decision ordering the restoration of the monument to its previous state has a discretionary character.

If we analyze the provision that forms the basis for issuing such a decision, the position expressed in the court's ruling raises fundamental doubts. According to Article 45.1 of the APHM, if preservation, restoration or construction works, or conservation or architectural research, have been carried out in relation to a monument entered into the register without the required permission from the voivodeship inspector for historical monuments, the authority shall issue a decision ordering the restitution of the monument to its previous state or the arrangement of the site, setting the time limit for carrying out these actions, or imposing an obligation to bring the monument to the best possible condition by means of the indicated methods and within the specified time limit.

Contrary to the Court's reasoning, the decision of the voivodship inspector for historical monuments is not discretionary, because the occurrence of the criteria set out in that provision obliges the

36 Voivodeship Administrative Court in Warsaw: 9 Mai 2013 (VII SA/Wa 143/13); 9 November 2015 (VII SA/Wa 220/15); 20 February 2018 (VII SA/Wa 1019/17).

37 Similarly, the judgment of the Voivodeship Administrative Court in Warsaw of 28 June 2017 (VII SA/Wa 1816/16) should be judged critically, because the court also mixed up the various areas of discretion of the monument protection authorities in a faulty way. 
authority to issue a decision. The authority has no discretion as to whether or not to take action, nor the type of the settlement. Therefore, there is a lack of basic elements characteristic of administrative discretion. What is more, it is also difficult to find the basis for a different type of decision-making in this provision. The grounds for interference are not based on indefinite terms. The authority is to examine whether the work is carried out without a required permit or in a manner that differs from the scope and conditions specified in the permit. There is no field of discretion in these arrangements. The only "undefined" element is the period of time in which the contractor is to restore the monument to its previous state or perform other prescribed actions. The logic indicates that the date should be determined in a realistic way, enabling the performance of duties. ${ }^{38}$

The proper understanding of the kind of discretion margin is not only a problem of theoretical correctness, but is of great practical importance. This becomes obvious if we look at the different attitudes of the courts to review different types of discretion.

While the review of the use of vague terms is more strict (additionally, it depends on the type of concept we are dealing with, as I mentioned above), the courts show more self-restraint in terms of typical administrative discretion. Therefore, incorrect determination of the type of discretion margin by the administrative court affects the incorrect narrowing of the scope of review. This, in consequence, may undermine the effectiveness of judicial review of the sovereign interference in the protection of historical monuments.

\subsection{The duty of the body to comprehensively explain the facts of the case}

The key elements of the judicial review of the discretionary power of historical monuments protection authorities include the assessment of compliance with all procedural requirements and proper explanation of the facts of the case. Insofar as the courts restrict intervention in the very substance of the discretionary decision, they, on the other hand, emphasize that the authority can only properly apply the discretionary powers if it has a proper, full picture of the case

This is clearly visible on the example of the basic form of historical monument protection, namely an entry in the register of monuments. As the courts argue, due to the discretionary nature of the decision, the body is particularly bound by general principles of administrative proceedings. In particular, the authority is required to take all necessary steps to thoroughly explain the facts of the case, must take into account the legitimate interest of the owner of the monument insofar as it does not interfere with the public interest in the protection of monuments, allow the parties an active participation in each stage of the proceedings and explain to the parties the prerequisites that the court is compliant with. The decision to enter an object in the register of historical monuments should be preceded by a thorough analysis of the legitimacy of such an action, taking into account the constitutional prohibition of violation of the essence of the property right. In addition, it should result from the determination of the undisputed historical value of the object. The justification of the decision should show that all circumstances relevant to the case have been considered and evaluated and the final resolution is their logical consequence. The judicial review of the decision on entry into the register of monuments consists in particular in checking whether its issuance was preceded by properly conducted proceedings and an explanation of the facts of the case. The administrative

38 A similar example of incorrect recognition that the body has discretionary powers, despite the lack of prerequisites in the provision is a judgment of Voivodeship Administrative Court in Warsaw of 15 March 2006 (IV SA/Wa 2213/05). 
court controls whether during the administrative procedure all necessary steps have been taken to clarify the factual situation, so that all evidence was gathered to determine whether there were any statutory grounds for issuing the decision. ${ }^{39}$

As indicated in the case law, the body must clearly indicate not only historical, artistic or scientific values, but also the current technical condition of the object with an indication of the impact of this state on the preservation of these assets. As a consequence, the body's knowledge about the historic values of a given object must be up to date. ${ }^{40}$

However, the question arises what it means in practice? How far does the court interfere with the decision of the body when it considers that the authority's findings as to the historical and scientific value of the object are not sufficient? In these matters, some general theses can no longer be formulated. It all depends on the individual approach of the court to a particular case. These problems regard another issue related to the independence of the authorities for the protection of monuments when finding the facts relevant in the case.

\subsection{The obligation to consult the external experts when assessing the conditions of interference}

When analyzing in section 1.2 the basic issues related to the specificity of discretion margin in the sphere of historical monuments protection, I signaled the problem of whether the historical monuments protection authority can independently make the necessary factual findings in the field of interference conditions. For example: whether, when evaluating if the object can be considered as a monument, the body can do it independently or it must consult an expert who has appropriate specialist knowledge in the field of history, art, technology. In turn, in case of imposing obligations related to the execution of specific construction works on the monument, the question arises: can the body independently determine the scope of this work, or must it consult an expert with relevant expertise in the field of construction or art history (for example as regards the obligation to restore the previous state of the object)?

Generally, courts recognize that regulations do not impose on historical monuments protection bodies an obligation to consult experts before entering an object into the register of monuments. The historical monuments protection authorities with specialized personnel in this area are able to objectively assess, based on the collected evidence, whether the object has historical qualities or not. ${ }^{41}$

The voivodship historical monuments conservator is a specialized body, and officials employed in his office should have specialist knowledge and experience in historical monuments protection. As a rule, the knowledge of officials should allow to determine the nature of a specific object. Authorities should have appropriate substantive competences in the cases examined, necessary even to assess whether the case should be examined by an expert. A specific object can be entered in the register of monuments without the need for a specialist opinion, if its historical character is obvious. It is not necessary that the authority ordered the expert opinion to be drawn up in order to confirm the historic values. Only in doubtful, controversial situations, in particular at conflicting

39 Voivodeship Administrative Court in Warsaw: 9 Mai 2013 (VII SA/Wa 143/13); 9 November 2015 (VII SA/Wa 220/15); 20 February 2018 (VII SA/Wa 1019/17).

40 Voivodeship Administrative Court in Warsaw: 1 March 2013 (VII SA/Wa 1897/12).

41 Voivodeship Administrative Court in Warsaw: 20 February 2018 (VII SA/Wa 1019/17). 
assessments as to the historic values of the object, the authority should allow evidence from an expert in a specific field. ${ }^{42}$

In another judgment, the Supreme Administrative Court pointed out that the assessment made by the monument protection authority, whether the monument should be entered into the register, is affected by the authority's professional awareness of the principles of methods of historical monument protection and existing organizational and technical possibilities. While the criteria for the assessment of historical values based on theoretical and legal premises should have universal character for the entire heritage, the methods of the preservation of these values are often diverse. Differences are determined by the specific features of the building that determine the conservation process. The individual approach of each preservation official and his knowledge depends on how the individual regulations will be interpreted. ${ }^{43}$

On the other hand, if the authority, when determining the facts relevant to the case, used the expertise of an external entity, this does not mean that in this way it violated the obligation to assess the case independently. The possibility of basing the decision on the opinion of an independent expert does not change the fact that the assessment of the criteria for an entry into the register of monuments is made by the historical monuments protection authority. ${ }^{44}$

In this case-law, one can see the expression of court's reliance upon the specialist knowledge possessed by monument protection authorities, necessary for the proper performance of the tasks entrusted to them. Of course, this reliance does not preclude the obligation to review the correctness of factual findings and to indicate possible errors. However, due to the limitations on the possibility of evidence taking by the court (see: paragraph 3) questioning the correctness of factual findings of a specialized body for the protection of monuments will be difficult.

\subsection{The review of the proportionality of interference and compliance with other constitutional standards in the field of fundamental rights}

As I mentioned in the introduction, almost all forms of protection of historical monuments are connected with far-reaching interference with the rights of the monument's owner, which inevitably results in conflicts between public and individual interests. For this reason, courts that review the legality of decisions of historical monuments protection bodies point to the need to respect the constitutional standards for the protection of fundamental rights, including the principles of proportionality and protection of property (Article 21, 31 and 64 of the Constitution of the Republic of Poland).

For example, in the judgment of 7 February 2018 (II OSK 909/16), the Supreme Administrative Court stated: "The decision to enter the object into the register of historical monuments must take into account the constitutional prohibition of violating the essence of the property right. In addition, the decision raises the legal obligations of the owner, because the Act imposes on the owner of a historical monument a number of restrictions connected with the disposal of the monument, as well as grants the owner certain rights resulting from the public status of the monument. For

\footnotetext{
42 Supreme Administrative Court: 14 December 2012 (II OSK 1512/11); 24 January 2017 (II OSK 1052/15); 20 November 2017 (II OSK 2926/16).

43 Supreme Administrative Court: 19 December 2017 (II OSK 1417/16).

44 Supreme Administrative Court: 26 January 2012 (II OSK 1885/11).
} 
this reason, the decision must be based on undisputed findings as to the ownership of the object to which it relates. These arrangements are crucial because they give the owner the basis for granting the status of a party to proceedings regarding the entry into the register of historical monuments." In another judgment, it was pointed out that due to the scope of interference in the sphere of rights of citizens, the institution of entering the surroundings of the monument in the register should be used with great caution. In particular, it is necessary to comply with the basic directives of the administrative procedure and prohibit the use of an extensive interpretation. ${ }^{45}$

The courts also place great emphasis on the proportionality of interference, which is particularly important in the case of acts based on discretionary powers. For example, one of the judgments pointed out that the decision to establish a cultural park is left to the administrative discretion of the competent commune council. This does not mean, however, that the act can be issued in an unrestricted manner. The body must respect the principle of proportionality, which precludes the establishment of prohibitions and orders over and above the real need. Because of the scope of interference in the sphere of citizens' rights the analyzed institution should be used with great caution, in particular taking into account the prohibition on the use of extensive interpretation. ${ }^{46}$

Proportionality makes it necessary to set precise limits of interference. As indicated by the Supreme Administrative Court in the judgment of 18September 2014(II OSK 629/13), the elementary requirement to make a decision about entering a urban settlement area or individual objects in the register of monuments, as well as establishing the boundaries of the monument's surroundings entered in the register is a clear indication of the motives followed by the body. It was therefore the duty of the body to demonstrate why the property belonging to the complainant should be under conservation supervision. Covering real estate property with historical monument preservation supervision is an exception and must therefore be very precisely justified.

It is an approach, convergent with contemporary European standards in the field of review of administrative discretion, emphasizing the proper balance of conflicting interests. Arguments representing the balancing of these interests should be presented by the authority in of the grounds for the sovereign interference. ${ }^{47}$

\subsection{Appropriate justification for the use of a specific form of interference}

The far-reaching effects of using forms of historical monuments protection mentioned in the previous paragraph, in particular, the "depth" of interference in the sphere of property rights, explain the requirement of special care for the justification of the decision. Furthermore, due to limited competences to enter into the very substance of the decision, the courts place particular emphasis on the review of the justification for interference. The general thesis is that the authority is obliged to explain and present rational arguments related to the circumstances of the case, why it was neces-

45 Voivodeship Administrative Court in Warsaw: 9 November 2015 (VII SA/Wa 220/15).

46 Ibid.

47 See the classical concept of "fair balance" in the case law of European Court on Human Rights: "[...] the Court must determine whether a fair balance was struck between the demands of the general interest of the community and the requirements of the protection of the individual's fundamental rights. The search for this balance is inherent in the whole of the Convention [...]" (Judgement of 23 September 1982, Sporrong \& Lönroth v. Sweden, case no 7152/75, \$ 69). See also: STĘPKOWSKI, A.: Zasada proporcjonalności w europejskiej kulturze prawnej. Warszawa: Liber, 2010, p. $216-220$. 
sary to use such and no other form of interference, why the body in this particular way settled, in a specific case, the conflict of public and individual interests.

As indicated in the case law, the basic requirement to make a decision about covering a specific object with historical monuments protection (including entering it into the register of historical monuments) is to indicate in unambiguous way what is the object of protection and to present reasons that justify such a qualification. The indication of what is the subject of protection must be so precise, that in the case of a decision ordering the restoration of the monument to its previous state or development of the area, there is no doubt what the previous state looked like and the decision is feasible. Imprecise definition of what is the subject of protection at the time of issuing such a decision prevents the implementation of later decisions. ${ }^{48}$

In the judgment of 18 September 2014 referred to above, the Supreme Administrative Court stressed that, within the limits set by the Act, it is possible to restrict ownership by prohibiting the planned investment as proposed by the investor. However, the case lacks a detailed explanation of why the protected area, in particular the property of the complainant, was protected. The acquisition of real estate with historical-monument protection supervision must be precisely justified. Certainly, it cannot be a decisive argument that some unfavorable transformations of the surrounding area currently under way can form a possibility of further degradation of this area, to the detriment of the historic area.

Another example is the judgment of the Supreme Administrative Court of 13 November 2008 (II OSK 1438/07), which states that classification of certain objects as parts of protected collections was left to the authorities appointed to protect historical monuments. Nevertheless, this assessment cannot be arbitrary. Entry into the register of historical monuments is a restriction of the right to property, and it can take place only by way of a statute and only to the extent that does not violate the essence of the right to property (Article 64.3 of the Constitution of Republic of Poland). Provisions restricting the right to property must be interpreted strictly and may only be applied in relation to actual facts covered by their disposition.

The courts put special emphasis on justifying the decisions in cases in which bodies operate under discretionary powers. As indicated in these judgments, the decision about entering an object into the register of historical monuments should be preceded by a thorough analysis of the legitimacy of such an entry, taking into account the constitutional prohibition on violating the essence of the right to property, and should result from undisputed values of the object as a historical monument. The justification of the decision should show that all circumstances relevant to the case have been considered and evaluated and the final resolution is their logical consequence. The authority issuing the decision based on the discretionary power is required to collect and thoroughly examine the evidence, as well as comprehensively justify its decision in terms of facts and law. ${ }^{49}$

\subsection{The problem of applying appropriate legal standards in cases of less formalized forms of interference}

As I signaled above (see: paragraph 1.2), the sources of discretion margin for historical monuments protection authorities may lie in the sphere of choosing less formalized activities. This choice may

48 Voivodeship Administrative Court in Warsaw: 15 June 2010 (I SA/Wa 78/10).

49 Voivodeship Administrative Court in Warsaw: 15 February 2013 (VII SA/Wa 2355/12); 9 Mai 2013 (VII SA/Wa 143/13); 9 November 2015 (VII SA/Wa 220/15); 20 February 2018 (VII SA/Wa 1019/17). 
be motivated by the desire to avoid a more formal procedure by the authority, which can in extreme cases be assessed as an abuse of the procedure.

An example may be the situation in which the organ decides to enter the object into the voivodeship lists of monuments (commune inventory of monuments; Article 22 of the APHM), instead of entering the object into the register of historical monuments. This first form is to a much lesser extent regulated by law, so it leaves the body for historical monuments protection more discretion margin. In addition, the scope of judicial review is limited in this case because the court, when reviewing the legality of an act, may appeal only to violation of the conditions laid down by law. For obvious reasons, the fewer conditions specified by law, the more difficult the role of the court reviewing the decision of the authority.

Entry of the object into the voivodeship lists of historical monuments is not even treated by the legislature as a form of historical monuments protection - it is not mentioned in Article 7 of the APHM, which contains a catalog of these forms. ${ }^{50}$ Nevertheless, this form of historical monuments protection is also associated with restrictions in the use of the monument being the object of protection, which is why the courts point to the need to retain some basic legal standards of interference in this case too. ${ }^{51}$

The jurisprudence opposes the treatment of such forms as being exempt from minimum standards, at least legal standards, important from the point of view of protecting the interests of the monument's owner. In addition, the use of simplified forms of historical monument protection does not exclude the possibility for the owner of the historical monument to seek legal protection before the administrative court. The owner of the historical monument is entitled to file a complaint to the administrative court against the act of entering the historical monument into the lists of historical monuments, therefore the act will be subject to judicial review of legality.

As indicated in the case law, the authority which keeps the list of historical monuments (commune inventory of monuments) is not obliged to carry out administrative proceedings regarding the inclusion of the object into the list, therefore, it does not make any administrative decision. The body's operation is a public administration activity regarding rights or obligations under the law, which is open to the administrative court pursuant to art. 3.2.4 of the LPAC. In this case, the legislature refrained from treating the actions of the regional historical monuments protection official as jurisdictional actions that require detailed regulation. The lack of provisions determining the course of proceedings results in the fact that the legality check boils down to the examination of the compliance of this action only with the provisions of administrative substantive law, excluding the provisions on administrative proceedings. ${ }^{52}$

On the other hand, case law emphasizes that the lack of formalization of the rules of procedure involving the inclusion of an object into the voivodeship list of historical monuments (commune inventory of monuments) does not mean that this activity can be performed without analyzing the reasons behind it, as well as documenting it even in a simplified form. Above all, the basic barrier to arbitrary decision-making by organs is the need to meet the basic objective prerequisite: even a less formalized form, which is an entry into the voivodeship list of monuments, can be used only in rela-

50 Similarly: Voivodeship Administrative Court in Poznań in the judgment of 15 September 2010 (IV SA/Po 428/10).

51 Voivodeship Administrative Court in Lodz: 20 March 2015 (II SA/Łd 1116/14): “The consequence of including immovable monuments in the communal list of monuments is the limitation of the exercise of ownership of the property, albeit of the lightest nature among all possible effects that the forms of protection of monuments listed in the Act cause."

52 Supreme Administrative Court: 26 October 2016 (II OSK 96/15). Similarly: Supreme Administrative Court: 21 January 2015 (II OSK 2189/13); Voivodeship Administrative Court in Rzeszów: 25 August 2016 (II SA/Rz 1596/15). 
tion to an object meeting the statutory criteria of a historical monument. Therefore, the court checks whether the body correctly recognized that the object constitutes a historical monument within the meaning of the Act. As the courts point out, it is obvious that the inclusion of the monument's card into the voivodeship list of historical monuments must result from the authority's conclusion that the object is characterized by features that justify the inclusion of a special form of protection due to its historical, artistic or scientific value. Only such an object that meets the definition of a historical monument can be included into the list of historical monuments. ${ }^{53}$

The lack of proper legal protection of the monument's owner in the case of using less formalized forms of protection of historical monuments raised doubts as to its compliance with constitutional and conventional standards for the protection of property. By virtue of a decision of 13 June 2018 (II OSK 2781/17), the Supreme Administrative Court asked the Constitutional Tribunal whether Art. 22. 5. 3 of the APHM is in accordance with art. 64.1 and 64.2 in conjunction with art. 31.33 of the Constitution of the Republic of Poland and art. 1 of Protocol No. 1 to the Convention on the Protection of Human Rights, to the extent that it restricts the ownership of real estate by allowing the object to be included into the commune inventory of monuments, without providing the owner with a guarantee of legal protection against such restriction. ${ }^{54}$

\section{CONCLUSION}

In the conclusions of the above considerations one can point out some basic theses, expressing the key elements of the methodology of examining the discretionary power of historical monument preservation authorities by Polish administrative courts.

First of all, administrative courts, when using terms that define different spheres of discretion margin, they are not always fully in line with the views of scholarly opinion. In some judgments, erroneous definitions of discretionary power may be found. It is also possible to note judgments in which, in the court's opinion, the body's discretion margin results from the lack of precise determination of the prerequisites for action taken by the historical monuments protection authority.

Secondly, the courts put a special emphasis on the obligation of the body to comprehensively explain the facts of the case. The fulfillment of this obligation is a key criterion for assessing the correctness of the body's discretionary powers. In this respect, the courts recognize that the monument protection bodies have sufficient competence to provide necessary findings requiring specialist knowledge in the field of history, art and technology, due to the specificity of the field and protected objects. The courts leave to the authorities the choice as to whether it is necessary to seek the assistance of external experts. Only in cases where the body's own knowledge is not sufficient for the proper fulfillment of the obligation of a comprehensive explanation of the facts of the case, the authority is obliged to seek external assistance in the form of an expert opinion as an entity with more extensive expertise.

53 Supreme Administrative Court: 20 November 2017 (II OSK 2926/16). Similarly: Supreme Administrative Court: 21 January 2015 (II OSK 2350/13); Voivodeship Administrative Court in Krakow: 8 February 2018 (II SA/Kr 1570/17); Voivodeship Administrative Court in Warsaw: 3 July 2013 (VII SA/Wa 2652/12).

54 By the time the article was submitted for publication, the legal question raised by the Supreme Administrative Court had not yet been examined by the Constitutional Court. 
Thirdly, the courts place great emphasis on the "culture of justification". An important object of review is justification of the form of the settlement. The body must fully explain, using suitably convincing arguments, that in the circumstances of the case, the body correctly exercised its discretion margin.

Fourthly, due to far-reaching interference in the sphere of rights of the historical monument's owner, the courts emphasize the need to make the act compliant with constitutional standards of interference in fundamental rights, in particular the principles of proportionality and protection of property. It is an approach convergent with contemporary European standards in the field of control of administrative discretion.

Fifth, in the case of less formal activities, less determined by legal regulation, the courts point to the importance of complying with procedural standards and proper justification for undertaking the action. This approach is justified by the lack of adequately detailed legal rules determining the actions of the authorities, which may lead to arbitrariness. Considering significant property restrictions that even involve the use of less formalized activities, the verification of compliance with the procedure and proper justification are basically the only instruments of judicial review and protection of an individual against the abuse of discretionary powers by historical monuments protection bodies.

\section{Bibliography:}

ACHTERBERG, N.: Allgemeines Verwaltungsrecht. Heidelberg: C.F. Müller, 1986.

BACHOF, O.: Beurteilungsspielraum, Ermessen und unbestimmter Rechtsbegriff. In: Juristenzeitung, 1955, no 4.

BRINKTRINE, R.: Verwaltungsermessen in Deutschland und England. Heidelberg: C. F. Müller, 1997.

CHAPUS, R.: Droit administratif général. Tome I. Paris: Montchrestien, 2001.

CRAIG, P.: Administrative Law. $7^{\text {th }}$ ed. London: Thomson, 2012.

DUBOUIS, L.: La théorie de l’abus de droit et la jurisprudence administrative. Paris: LGDJ, 1962.

DWORKIN, R.: Taking Rights Seriously. Massachusets: Harvard University Press, 1978.

HÄFELIN, U. - MÜLLER, G.: Grundriss des Allgemeinen Verwaltungsrechts. Zürich: Schulthess, 1998.

JAŚKOWSKA M.: Uznanie administracyjne a inne formy władzy dyskrecjonalnej administracji publicznej. In: HAUSER, R. - NIEWIADOMSKI, Z. - WRÓBEL, A. (eds.): System prawa administracyjnego. Tom I. Instytucje prawa administracyjnego. Warszawa: C.H. Beck, 2010.

JAKIMOWICZ, W.: Wykładnia w prawie administracyjnym, Kraków: Zakamycze, 2006.

KOBYLIŃSKI, Z. - WYSOCKI, J.: Ujęcie problematyki ochrony zabytków archeologicznych w ustawie o ochronie zabytków i opiece nad zabytkami - stan obecny i postulaty zmian. In: ZEIDLER, K. (ed.): Prawo ochrony zabytków. Warszawa-Gdańsk: Wolters Kluwer, 2014.

KOWALSKI, W. - ZALASIŃSKA, K.: Strategia regulacji prawa ochrony dziedzictwa kulturowego. In: ZEIDLER, K. (ed.): Prawo ochrony zabytków. Warszawa-Gdańsk: Wolters Kluwer, 2014.

LESZCZYŃSKI, L.: Stosowanie generalnych klauzul odsyłających. Kraków: Zakamycze, 2001.

MAURER, H.: Allgemeines Verwaltungsrecht. München: C.H. Beck, 2011.

OSSENBÜHL, F.: Rechtliche Gebundenheit und Ermessen der Verwaltung. In: ERICHSEN, H.-U. (ed.): Allgemeines Verwaltungsrecht. Berlin-New York: Walter de Gruyter, 1995.

PARCHOMIUK, J.: Nadużycie prawa w prawie administracyjnym. Warszawa: C.H. Beck, 2018.

PŁAŻYŃSKA, K.: Świadectwo minionej epoki czy dobro kultury współczesnej? Problemy ochrony prawnej architektury nowoczesnej. In: ZEIDLER, K. (ed.): Prawo ochrony zabytków. Warszawa-Gdańsk: Wolters Kluwer, 2014. 
PROTT, L.V. - O’KEEFE, P. J.: Cultural Heritage or Cultural Property. In: International Journal of Cultural Property, 1992, no 1 .

RODE, L.-H.: $\$ 40$ VwVfG und die deutsche Ermessenslehre. Frankfurt am Main: Peter Lang, 2000.

SCHWARZE, J.: Grundlinien und neure Entwicklungen des Verwaltungsrechtschutzes in Frankreich und Deutschland. In: Neue Zeitschrift für Verwaltungsrecht, 1996, no. 1.

SCHENKE, W.-R.: Verwaltungsprozessrecht. Heidelberg - München: C.F. Müller, 2012.

SERRAND, P.: Le contrôle juridictionnel du pouvoir discrétionnaire de l'administration à travers la jurisprudence récente. In : Rev. du droit public, 2012, no 4.

STĘPKOWSKI, A.: Zasada proporcjonalności w europejskiej kulturze prawnej. Warszawa: Liber, 2010.

TAJCHMAN, J.: Konwencja o ochronie dziedzictwa architektonicznego Europy a przyczyny jego degradacji w Polsce oraz drogi do jej powstrzymania. In: ZEIDLER, K. (ed.): Prawo ochrony zabytków. Warszawa-Gdańsk: Wolters Kluwer, 2014.

TOTH, A.: The Oxford Encyclopedia of European Community Law. Oxford: Oxford University Press, 2005.

TRZCIŃSKI, M.: Definicja zabytku archeologicznego - problemy i kontrowersje wokół stosowania prawa. In: ZEIDLER, K. (ed.): Prawo ochrony zabytków. Warszawa-Gdańsk: Wolters Kluwer, 2014.

VAN RAEPENBUSCH, S : Droit institutionnel de l'Union et des Communautés européennes. Bruxelles: Larcier, 2001. VEDEL, G. - DELVOLVÉ, P : Droit adminitstratif, T. 1. Paris: Presses Universitaires de France, 1992.

WADE, W. - FORSYTH, Ch: Administrative Law. $9^{\text {th }}$ ed. New York: Oxford University Press, 2004.

WOLFF, H. J. - BACHOF, O. - STOBER, R.: Verwaltungsrecht I. München: C.H. Beck, 1994.

WOOLF, H. Lord - JOWELL, J. - LE SUEUR, A.: De Smith's Judicial Review. $6^{\text {th }}$ ed. London: Sweet \& Maxwell, 2007. WRÓBLEWSKI, J.: Wartości a decyzja sądowa. Wrocław: Ossolineum, 1973.

ZEIDLER, K.: O znaczeniu teorii konserwatorskiej w procesie stosowania prawa. In: SZMYGIN, B. (ed.): Współczesne problemy teorii konserwatorskiej w Polsce. Warszawa-Lublin: Międzynarodowa Rada Ochrony Zabytków ICOMOS, 2008.

\section{Contact information:}

Dr. Jerzy Parchomiuk

parchom@kul.pl

John Paul II Catholic University of Lublin

Department of Administrative Law

Al. Raclawickie 14

20-950 Lublin

Poland 